\title{
SOUTHWEST SUBTROPICAL PACIFIC SURFACE WATER RADIOCARBON IN A HIGH-RESOLUTION CORAL RECORD
}

\author{
Thomas P Guilderson ${ }^{1,2} \bullet$ Daniel P Schrag ${ }^{2} \bullet$ Ethan Goddard $^{2} \bullet$ Michaele Kashgarian $^{1} \bullet$ \\ Gerard M Wellington ${ }^{3} \cdot$ Braddock K Linsley $^{4}$
}

ABSTRACT. We have generated a high-resolution coral $\Delta^{14} \mathrm{C}$ record from the southwest subtropical Pacific spanning the last 50 yr. Prebomb (1950-1956) $\Delta^{14} \mathrm{C}$ values average $-52 \%$. Values begin to increase in 1957 , reaching a maximum in the early 1970 s, about $10 \mathrm{yr}$ after the atmospheric peak. There is a consistent 10-15\%o seasonal cycle whose relationship with vertical mixing evolves as a consequence of the penetration of the bomb transient into subsurface waters. Comparison of this record with that simulated in an ocean general circulation model highlights the difficulty in modeling vertical exchange processes.

\section{INTRODUCTION}

One of the fundamental questions in tropical oceanography is what dynamic processes determine the mean vertical structure of the Pacific thermocline. Equally important is how these processes will evolve in response to rising atmospheric $\mathrm{CO}_{2}$ concentrations (Houghton et al. 1996). Parameter sensitivity tests with the coupled Zebiak and Cane ocean model have shown that varying the vertical structure of the tropical thermocline has the strongest impact on the decadal nature of the model's El Niño-Southern Oscillation (ENSO) behavior (Zebiak and Cane 1991). Thus, there is a potential to alter the coupled ocean-atmosphere system's internal oscillations such as ENSO.

Guilderson and Schrag (1998) presented evidence indicating that the vertical structure of the Pacific tropical thermocline along the equator changed in 1976 such that the contribution of deeper, colder water was reduced. Since 1976, there has been an increase in the frequency and severity of ENSO events (e.g. Trenberth and Hoar 1996); the 1997-1998 and 1982-1983 events are the two strongest events on record, and the sustained "near" ENSO of 1990-1995 is unusual over the 120-yr instrumental record. Moreover, there appears to have been a shift in the frequency of ENSO warm events to a more regular 5-yr periodicity. As of yet, it remains uncertain whether this shift is part of an underlying dynamically driven natural variability, a stochastic response, or the result of anthropogenic forcing (Trenberth and Hoar 1996; Rajagopalan et al. 1997).

The water feeding tropical Pacific upwelling originates as extra-tropical surface water which, during winter months, becomes more dense and sinks to intermediate depths (Bryden and Brady 1985; Tsuchiya et al. 1989). Potential temperature and salinity measurements indicate that the southern hemisphere is the dominant source of tropical thermocline water (Knauss 1966; Tsuchiya 1968; Tsuchiya et al. 1989; Wyrtki and Kilonsky 1984). This subtropical source water enters the equatorial undercurrent (EUC, constrained by the $24.0-26.0 \mathrm{~kg} \mathrm{~m}^{-3}$ isopycnals; Wyrtki and Kilonsky 1984) in the western Pacific, and during its eastward transit and prior to outcropping in the east entrain a significant amount of deeper sub-thermocline water, in addition to water from shallower depths.

Sensitivity experiments in a simple model (Gu and Philander 1997) build upon observations from the subtropical north Pacific, which document the formation of sub-surface thermal anomalies (Deser et al. 1996) and show that the natural feedback processes between the extra-tropics and trop-

\footnotetext{
${ }^{1}$ Center for Accelerator Mass Spectrometry, Lawrence Livermore National Laboratory, Livermore, California 94551, USA

${ }^{2}$ Laboratory for Geochemical Oceanography, Department of Earth and Planetary Sciences, Harvard University, Cambridge, Massachusetts 02138, USA

${ }^{3}$ Department of Biology and Biochemistry, University of Houston, Houston, Texas 77204, USA

${ }^{4}$ Department of Earth and Atmospheric Sciences, University at Albany, State University of New York, Albany, New York 12222, USA
} 
ics can result in continual interdecadal climate fluctuations linked by these subsurface thermal anomalies. Zhang et al. (1998) take this one step further and propose that the 1976 change in ENSO frequency is due to warm subsurface anomalies propagating from the north Pacific and impacting the tropical Pacific thermocline. This hypothesis is at odds with observations of the dominance of southern hemisphere water in the tropical thermocline. More recent model experiments implicate the southern subtropics, in particular the amount and thermal characteristics of winter mode waters, as a dynamic driver of changes in ENSO frequency (Rodgers et al. 1999). The dearth of historical observations in the subtropical South Pacific makes it difficult to document past interannual to decadal variability in the production of subtropical "mode" waters (e.g. Pickard and Emery 1982) and what the (potential) impact on the tropical thermocline has been.

Sub-annual radiocarbon measurements derived from coral skeletal material which accurately records $\Delta^{14} \mathrm{C}$ of the $\Sigma \mathrm{CO}_{2}$ has added to our knowledge of the general shallow circulation of the Pacific (Druffel 1987; Moore et al. 1997; Guilderson et al. 1998; Guilderson and Schrag 1998 among others) augmenting the results derived from GEOSECS (Östlund and Stuiver 1980; Broecker et al. 1985) and WOCE (Key et al. 1996). Although the WOCE program continues to produce seawater ${ }^{14} \mathrm{C}$ analysis today, there are notable limitations to a shipboard sampling, primarily the inability to monitor ocean conditions continuously. For ${ }^{14} \mathrm{C}$ in the deep ocean, this is not a problem because the transport is relatively slow and the gradients are relatively low. For the surface ocean, where ${ }^{14} \mathrm{C}$ gradients are highest and transport is rapid, it has been demonstrated that temporal variability is of the same order as spatial variability (e.g. Guilderson et al. 1998), an observation that is lost in discrete analyses like GEOSECS and WOCE whose "snapshots" of bomb- ${ }^{14} \mathrm{C}$ are integrations of around $20 \mathrm{yr}$ and $40 \mathrm{yr}$ (respectively) of ocean dynamics. Over the timeframe of interest, radioactive decay is negligible such that $\Delta^{14} \mathrm{C}$ is a quasi-conservative, passive advective tracer, and therefore time series such as those derived from archives such as hermatypic corals can augment historical, conventional (temperature, salinity) observations especially in times and regions where observations are sparse.

We have generated a high-resolution coral $\Delta^{14} \mathrm{C}$ record spanning about the last $50 \mathrm{yr}$ from Rarotonga (nominally $21^{\circ} \mathrm{S}, 160^{\circ} \mathrm{W}$, Figure 1 ) to determine the $\Delta^{14} \mathrm{C}$ variability in southwest subtropical Pacific surface waters. Climatological mean sea surface temperature (SST) minima of around $24.0{ }^{\circ} \mathrm{C}$ occur during August and September, and maximum SSTs of around $27.5^{\circ} \mathrm{C}$ occur during February and March (Levitus and Boyer 1994; Reynolds and Smith 1994). During austral winter, radiative cooling and increased evaporation in conjunction with seasonally increasing winds (Legler and O'Brien 1988) leads to densities in excess of about $24.5 \mathrm{~kg} \mathrm{~m}^{-3}$ and mixing to depths of about $100 \mathrm{~m}$ (Figure 2; see also Monterey and Levitus 1997). Therefore, winter or cold season $\Delta^{14} \mathrm{C}$ as recorded in the coral's skeleton is equal to that of the newly subducted water. Historical hydrographic observations in the southwest subtropical Pacific are sparse; fewer than 2000 casts are available in an extended subtropical grid $19^{\circ} \mathrm{S}-29^{\circ} \mathrm{S}, 165^{\circ} \mathrm{E}-155^{\circ} \mathrm{W}$ (SIO/NODC database; 1950-1986) and fewer than 10 in a $1^{\circ}$ grid around Rarotonga, and thus these data will assist in understanding and modeling the processes controlling the tropical thermocline and the production of subsurface water masses (e.g. Rodgers et al. 1999).

\section{METHODS}

A large Porites lutea coral located in open marine conditions off Rarotonga $\left(21^{\circ} 14^{\prime} \mathrm{S}, 159^{\circ} 49^{\prime} \mathrm{W}\right)$ was drilled in March of 1997. The top of the coral was located at a depth of about $18 \mathrm{~m}$ ( $60 \mathrm{feet})$. The cores $(7.6 \mathrm{~cm}$ diameter, and up to $3.7 \mathrm{~m}$ total length) were cut into about $1-\mathrm{cm}$ slabs, cleaned in distilled water, and air dried. X-radiographs were made and after identifying the major vertical growth 
axis, the coral was sequentially sampled at 1-mm increments with a low-speed drill. Splits ( 1 mg) were reacted in vacuo in a modified autocarbonate device at $90{ }^{\circ} \mathrm{C}$ and the purified $\mathrm{CO}_{2}$ analyzed on a gas source stable isotope ratio mass spectrometer. Additional splits (also $\sim 1 \mathrm{mg}$ ) were analyzed by ICP-AES for Sr, and Ca (Schrag 1999). The $\delta^{18} \mathrm{O}$ and [Sr/Ca] results were individually mapped to the Kaplan OI and IGOSS sea surface temperature time-series for the grid containing Rarotonga (Kaplan et al. 1998; Reynolds and Smith 1994), indicating an average linear extension rate of $15.5 \mathrm{~mm}$ per year over about the last $50 \mathrm{yr}$ (Wellington et al. in preparation).

The seasonally resolved age model indicates that the upper $740 \mathrm{~mm}$ covers 1950 to present with an age model error for any given sample of less than \pm 1 month. This exceptional resolution is a consequence of the linear extension rate (where we obtain $\sim 15$ samples per year) and the relatively large seasonal cycle in sea surface temperature $\left(\sim 3.5^{\circ} \mathrm{C}\right)$ which allows for detailed chronological mapping. For the interval $1959-1997$, approximately every other sample was analyzed for ${ }^{14} \mathrm{C}$ (i.e. $\sim 8$ discrete samples per year). For the remaining sequence, every sample was analyzed ( $\sim 15$ discrete samples per year). ${ }^{14} \mathrm{C}$ sample splits (nominally $10 \mathrm{mg}$ ) were placed in individual reaction chambers, evacuated, heated, and then acidified with orthophosphoric acid at $90{ }^{\circ} \mathrm{C}$. The evolved $\mathrm{CO}_{2}$ was purified, trapped, and converted to graphite in the presence of cobalt catalyst in individual reactors (Vogel et al. 1987). Graphite targets were measured at the Center for Accelerator Mass Spectrometry, Lawrence Livermore National Laboratory (Davis et al. 1990). ${ }^{14} \mathrm{C}$ results are reported as "agecorrected" $\Delta{ }^{14} \mathrm{C}(\% \circ)$ as defined by Stuiver and Polach (1977). Analytical precision (i.e. external reproducibility) and accuracy of the ${ }^{14} \mathrm{C}$ measurements is $\pm 4 \%$ as monitored by the concurrent analysis of an in-house coral standard $\left(1 \sigma \mathrm{n}=33\right.$, normalized to $\left.\mathrm{F}_{\text {modern }}=1.0\right)$, and officially distributed secondary standards. Standards and unknowns were analyzed in pre-defined groups and cycled $\left(25,000{ }^{14} \mathrm{C}\right.$ counts per cycle) in such a manner as to acquire at least $100,000{ }^{14} \mathrm{C}$ counts. Untreated, ${ }^{14} \mathrm{C}$ barren calcite analyzed concurrently with the coral samples had an average $\mathrm{F}_{\text {modern }}=0.0016 \pm$ $0.0004(n=20)$. The background error is added in quadrature to the larger of the internal error (counting statistics) or external error of the n-data acquisition cycles utilized in calculating the unknown's ${ }^{14} \mathrm{C} /{ }^{13} \mathrm{C}$ ratio. In practice, background errors contribute little to no error in these measurements because the unknowns are so close to modern $(\mathrm{Fm}=1.0)$.

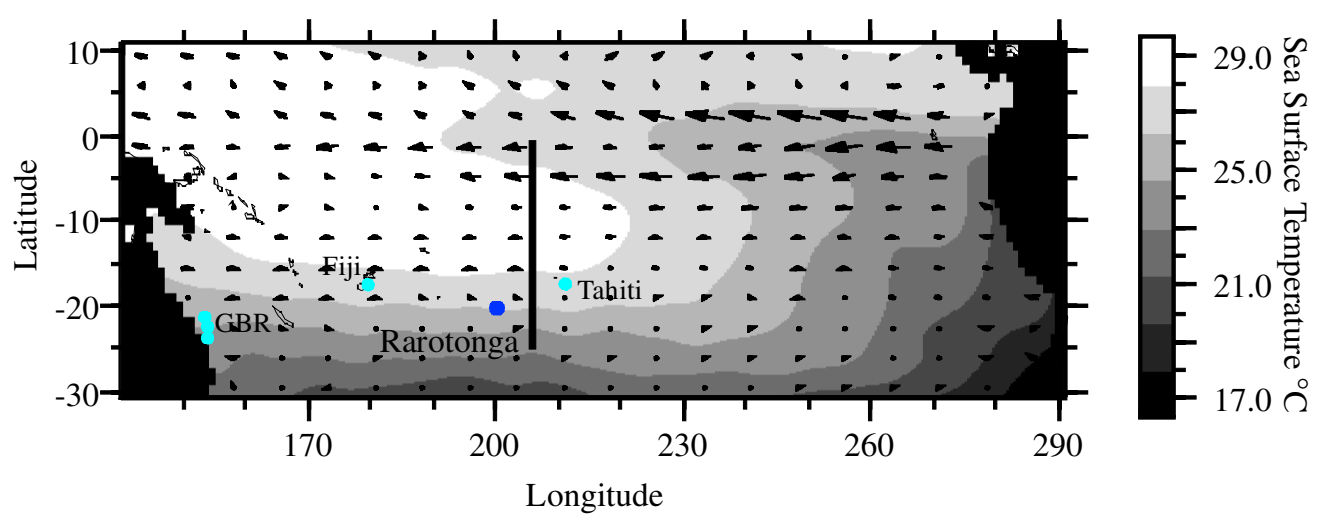

Figure 1 South Pacific mean annual sea surface temperature (Levitus and Boyer 1994). Rarotonga and other locations as discussed in the text (Tahiti, Fiji, Great Barrier Reef) are marked as is the meridional profile along $155^{\circ} \mathrm{W}$ shown in Figure 2. Vector overlay is the mean annual 5-m current velocities as simulated in the National Centers Environmental Prediction EMC reanalysis project (digitally available online at: www.emc.ncep.noaa.gov). 


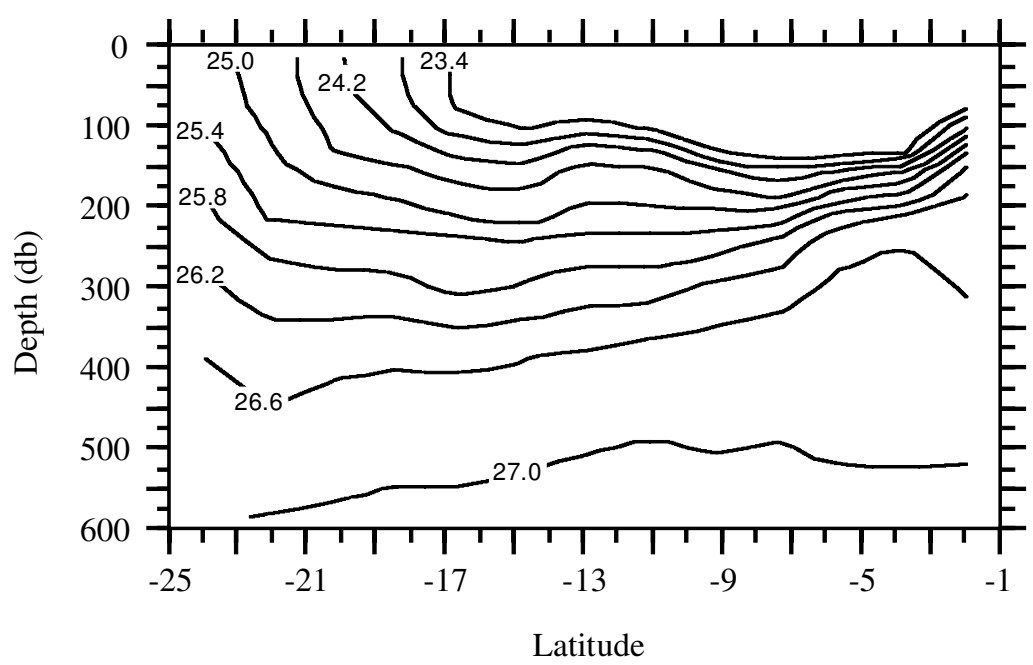

Figure 2 Isopycnal $\left(\mathrm{kg} \mathrm{m}^{-3}\right)$ meridional-depth profile taken by the R/V Argos near Rarotonga during austral winter $\left(155^{\circ} \mathrm{W}\right.$, Sept-Oct 1969$)$ showing outcropping of about 24.6 isopycnals at $21^{\circ} \mathrm{S}$.

\section{RESULTS}

Between 1950 and March of 1997, $\Delta^{14} \mathrm{C}$ at Rarotonga has a dynamic range of $274 \%$, from a low of $-61 \%$ o (1953.38) to a high of $+213 \%$ o (1972.07, 1974.29; see Figure 3$)$. The prebomb interval (1950-1956) averages $-52 \%$ and annual averages have a strong linear trend $(-0.75 \%$ o per year, $r-$ squared 0.60). Levels begin to rise in 1957, and between 1957 and 1963, mean annual values rise at a near monotonic rate of $10 \%$ per year. The most rapid increase occurs in the 4-yr interval encompassing 1964-1967 when mean annual values increased at a rate in excess of $22 \%$ per year. The post-bomb maxima occurs in the early 1970s (mean annual +151 to $+153 \%$ o, 1972-1974), about 10 yr after the atmospheric maximum and similar to other subtropical records (Druffel 1987; Toggweiler et al. 1991). Values have been decreasing more or less steadily since 1975, with distinct drops of around $-10 \%$ per year in 1977, 1990, and 1994.

\section{DISCUSSION}

\section{Radiocarbon Time Series}

The Rarotonga ${ }^{14} \mathrm{C}$ record is similar to previously published coarse resolution records from other nearby subtropical locations (Figure 3). Over the same pre-bomb interval (1950-1956), Rarotonga values are $12 \%$ o higher than those recovered from Viti Levu (Fiji) in the southwest Pacific (-64\%o average; Toggweiler et al. 1991), and about $8 \%$ o higher than a pre-bomb shell sample from Tahiti to the northeast ( $-60 \%$; Stuiver et al. 1986). Pre-bomb measurements in corals from the more distant Great Barrier Reef (GBR) are -52\%o (Druffel and Griffin 1995) and similar to those observed at Rarotonga. Broad, diffuse flow of the southward branch of the South Equatorial Current (SEC) feeds the East Australian Current which ultimately bathes the GBR region which may explain the similarity in values between these two locations. Between 1960 and 1965 when the atmospheric forcing is the largest ( 650\%o in 1965; Manning and Melhuish 1994) similar $\Delta^{14} \mathrm{C}$ values are observed at Rarotonga and Viti Levu. After the atmospheric maximum in 1965, the records from Tahiti and Viti Levu track each other, whereas the Rarotonga record continues to rise at a faster rate. 
The post-bomb maximum is depressed by nearly 20\%o at Tahiti and Viti Levu (136\%o, 1973; and $135 \%$, 1974 respectively) relative to Rarotonga. After the post-bomb maximum, Viti Levu $\Delta^{14} \mathrm{C}$ decreases more rapidly than that of Rarotonga. In the presence of a diluting source such as mixing in a constant value lower- ${ }^{14} \mathrm{C}$ water, it is possible to change the post-bomb amplitude but not necessarily the timing. The timing and amplitude of the $\Delta^{14} \mathrm{C}$ post-bomb maximum is a diagnostic of airsea $\mathrm{CO}_{2}$ exchange and the mixing of bomb ${ }^{14} \mathrm{CO}_{2}$ out of the surface mixed layer and into (and with) the deeper reservoirs, to actually delay the timing of the post-bomb peak requires an advective or dynamic process (c.f. Guilderson and Schrag 1998; Guilderson et al. 1999). Because the atmospheric forcing is similar for all south Pacific records, the differences reflect variable vertical exchange of surface waters and the penetration of bomb- ${ }^{14} \mathrm{C}$ into and with subsurface waters for the respective locations.

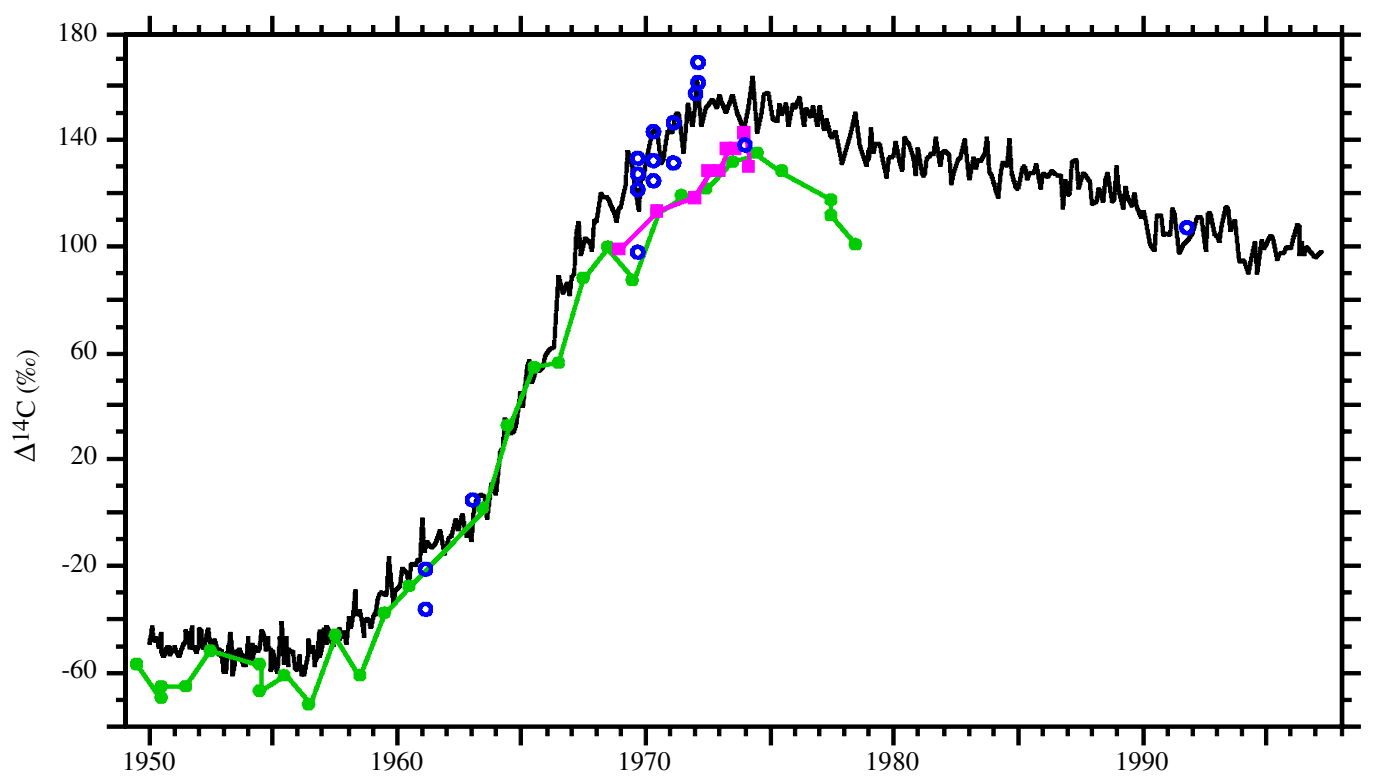

Age

Figure 3 Rarotonga data to time (thin solid line; $\pm 4 \% 01 \sigma$ ), historical water measurements analyzed in the La Jolla radiocarbon laboratory, GEOSECS Station 263, and WOCE P16 Station 215 (open circles, Linick 1978; Östlund and Stuiver 1980; Key et al. 1996), and previously reported coarse resolution (annual to biannual) coral records from other locations in the southern subtropics: Viti Levu (solid circles, $18^{\circ} \mathrm{S}, 179^{\circ} \mathrm{E}$, Toggweiler et al. 1991), Tahiti (solid squares, $17^{\circ} \mathrm{S}, 150^{\circ} \mathrm{W}$; Druffel 1987). Data from Viti Levu have been "age-corrected" to be consistent with the Druffel data and this study.

The Rarotonga time series exhibits seasonality across the expanse of the record (c.f. Figure 3). To extract the seasonal component of the coral time-series, we have high-pass filtered the record with a 20-weight Tukey-Cosine filter (half amplitude at $1 \mathrm{yr}$ ) using the "Arand" package (P Howell, personal communication). In general, the seasonal amplitude is about 10-15\%o (Figure 4) but varies from around 5\%o (e.g. 1962) to a high of around 25\%o (e.g. 1969). In a simple one-dimensional model, we would expect that $\Delta^{14} \mathrm{C}$ and SST follow each other closely; during times of winter mixing, the surface waters mix with colder subsurface waters which would tend to have lower ${ }^{14} \mathrm{C}$. The two records are nearly in-phase supporting this simple one-dimensional view until 1980. Between 1980 and 1985, the records are completely out of phase, and the phasing is variable until the conclusion of the record. The change in the phasing of the seasonal cycle between $\Delta^{14} \mathrm{C}$ and temperature 
reflects subsurface dynamics and indicates that lateral advection and vertical mixing has yielded higher $\Delta^{14} \mathrm{C}$ in subsurface waters than the overlying surface waters (c.f. Quay et al. 1983; Key et al. 1996). In 1991 along $150^{\circ} \mathrm{W}$ (WOCE line P16), southern hemisphere subtropical subsurface water had the highest $\Delta^{14} \mathrm{C}$ concentrations observed (Key et al. 1996). We therefore expect that a complicated seasonality (with respect to SST) will continue until the bomb transient's amplitude is further mixed into and with subthermocline waters.

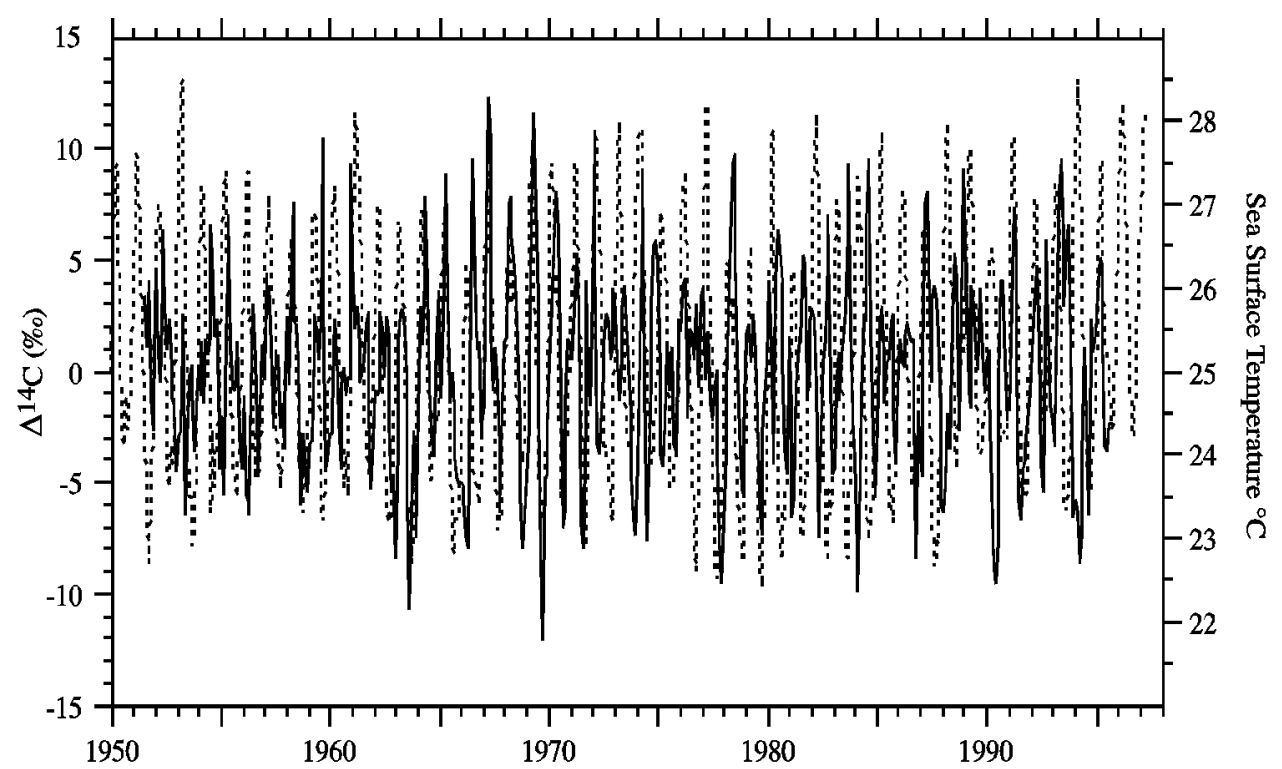

Figure 4 Seasonal variability in the Rarotonga $\Delta^{14} \mathrm{C}$ record (solid line) and sea surface temperatures (dotted line; Kaplan OI \& IGOSS SSTs, Kaplan et al. 1998; Reynolds and Smith 1994). Note that prior to about $1980, \Delta^{14} \mathrm{C}$ and SST are in phase, whereas post 1980 they are not. The coral $\Delta{ }^{14} \mathrm{C}$ record has been passed through a 20 -weight Tukey Cosine high-pass filter (half amplitude at $1 \mathrm{yr}$ ). The tails of the filtered record have been clipped.

\section{Radiocarbon and Ocean Modeling}

Oceanic uptake and transport of bomb ${ }^{14} \mathrm{C}$ has been a useful diagnostic in ocean-only GCMs to test parameterizations of sub-grid scale motions and gas transfer between the ocean and atmosphere (e.g. Toggweiler et al. 1991; Duffy et al. 1995; Rodgers et al. 1997; Rodgers et al. 1999). Atmospheric nuclear testing resulted in an excess of ${ }^{14} \mathrm{C}$, which has augmented the natural ${ }^{14} \mathrm{C}$ gradient between surface and subsurface waters. This contrast makes the distribution of ${ }^{14} \mathrm{C}$ in the surface ocean particularly sensitive to vertical mixing and thus the timing and amplitude of the post-bomb $\Delta^{14} \mathrm{C}$ maximum (i.e., the difference between the mean pre-bomb baseline $\Delta^{14} \mathrm{C}$ and when the record has its highest value) is indicative of air-sea gas transfer and vertical exchange within the ocean. In general, an early post-bomb peak indicates a stratified upper-ocean (air-sea exchange brings the ${ }^{14} \mathrm{C}$ content in the water towards equilibrium) whereas a later peak implies an advective process. With respect to amplitude, a small bomb perturbation indicates a large portion of sub-surface water (with a low- ${ }^{14} \mathrm{C}$ signature) mixing into the surface, and a large amplitude indicates less mixing with subsurface waters. The strength of model-data comparisons lie in the fact that the distribution of bomb${ }^{14} \mathrm{C}$ is very sensitive to vertical exchange processes, more so than even temperature (e.g. Duffy et al. 1995). Model simulations of the uptake and redistribution of bomb- ${ }^{14} \mathrm{C}$ in the subtropics exhibit an 
early post-bomb maximum and in general with too much amplitude (e.g. Toggweiler et al. 1991; Guilderson et al. 1999; Rodgers et al. 1999) indicating that the water column is overly stratified and production of subtropical subsurface water masses (winter or mode-water) is inaccurately reproduced.

\section{CONCLUSION}

We have generated a high-resolution $\Delta^{14} \mathrm{C}$ coral-based record spanning the post-bomb interval from Rarotonga $\left(21^{\circ} \mathrm{S}, 160^{\circ} \mathrm{W}\right)$ in the southwest subtropical Pacific. The results presented here document $10-15 \%$ seasonality from the pre-bomb (1950-1956, average -52\%o) through the post-bomb maximum in the early 1970s (annual average $\sim+152 \%$ ) and to the present (annual average 100\%o in 1996). The long-term trend reflects the penetration of bomb- ${ }^{14} \mathrm{C}$ into surface waters and the subsequent mixing with subsurface water masses. The ${ }^{14} \mathrm{C}$ seasonal cycle evolves from one that is generally in phase with sea surface temperatures reflecting vertical mixing with colder, lower- ${ }^{14} \mathrm{C}$ subsurface water, to a more complicated one where ${ }^{14} \mathrm{C}$ and sea surface temperatures can be completely out of phase. This evolution is a consequence of lateral advection and vertical mixing of the bomb-transient into the subsurface waters of the subtropical south Pacific such that the subsurface water's ${ }^{14} \mathrm{C}$ content is non-stationary.

Ocean model simulations of the bomb-transient highlights the difficulty in modeling vertical exchange processes where models have inaccurate vertical mixing during winter. Winter vertical mixing in the southern subtropics results in the formation of subtropical subsurface waters, a key component in the tropical Pacific thermocline. Future efforts to model the dynamical processes controlling the vertical structure of the tropical Pacific thermocline need to have better representation of the formation of subsurface water masses in order to accurately predict possible future changes in such phenomena as ENSO in response to rising atmospheric $\mathrm{CO}_{2}$ concentrations. Data such as those presented here are therefore key in diagnosing deficiencies in ocean modeling.

\section{ACKNOWLEDGMENTS}

We thank Paula Zermenko for pressing more than her share of graphite targets. The "Arand" spectral package is maintained and distributed by Phil Howell, Brown University. This manuscript benefitted from comments by W Beck and an anonymous reviewer. This work was supported by a grant to M Kashgarian (LLNL 98-ERI-002) and to D Schrag from NSF's program in Physical Oceanography (OCE-9796253). Funding for the collection of the coral cores was supplied by the NSF (ATM9619035) to $\mathrm{G}$ Wellington. ${ }^{14} \mathrm{C}$ analyses were performed under the auspices of the US Department of Energy by Lawrence Livermore National Laboratory (contract W-7405-Eng-48).

\section{REFERENCES}

Broecker WS, Peng T-H, Östlund G, Stuiver M. 1985. The distribution of bomb radiocarbon in the ocean. Journal of Geophysical Research 90:6953-70.

Bryden HL, Brady EC. 1985. Diagnostic model of the 3dimensional circulation in the upper equatorial Pacific ocean. Journal of Physical Oceanography 15:125573.

Davis JC et al. 1990. LLNL/UC AMS facility and research program. Nuclear Instruments and Methods in Physics Research B52:269-72.

Druffel ERM. 1987. Bomb radiocarbon in the Pacific: annual and seasonal timescale variations. Journal of
Marine Research 45:667-98.

Druffel ERM, Griffin S. 1995. Regional variability of surface ocean radiocarbon from southern Great Barrier Reef corals. Radiocarbon 37(2):517-24.

Duffy PB, Caldeira K. 1995. Three-dimensional model calculation of ocean uptake of bomb ${ }^{14} \mathrm{C}$ and implications for the global budget of bomb ${ }^{14} \mathrm{C}$. Global Biogeochemical Cycles 9:373-5.

Gu D, Philander SGH. 1997. Interdecadal climate fluctuations that depend on exchanges between the tropics and extratropics. Science 275:805-7.

Guilderson TP, Schrag DP. 1998. Abrupt shift in subsur- 
face temperatures in the Eastern Tropical Pacific associated with recent changes in El Niño. Science 281: 240-3.

Guilderson TP, Schrag DP, Kashgarian M, Southon J. 1998. Radiocarbon variability in the western equatorial Pacific inferred from a high-resolution coral record from Nauru Island. Journal of Geophysical Research 103:24641-50.

Guilderson TP, Caldeira K, Duffy PB. 1999. Radiocarbon as a diagnostic tracer in ocean and carbon cycle modeling. Global Biogeochemical Cycles. Forthcoming.

Houghton JT et al. 1996. Climate change 1995, the science of climate change. Cambridge: Press Syndicate of the University of Cambridge. $572 \mathrm{p}$.

Kaplan A. 1998. Analyses of global sea surface temperature 1856-1991. Journal of Geophysical Research 103:18,567-89.

Key RM, Quay PD, Jones GA, McNichol AP, Von Reden K, Schneider R. 1996. WOCE AMS radiocarbon I: Pacific Ocean results (P6, P16, and P17). Radiocarbon 38(3):425-518.

Knauss JA. 1966. Further measurements and observations on the Cromwell Current. Journal of Marine Research 24:205-40.

Legler DM, O'Brien JJ. 1988. Tropical Pacific wind stress analysis for TOGA, IOC Time series of ocean measurements. IOC Technical Series 33, Vol 4. UNESCO (digitally updated).

Levitus S, Boyer T. 1994. World ocean atlas 1994. Washington DC: National Oceanic and Atmospheric Administration, US Department of Commererce. Vol 4. $117 \mathrm{p}$.

Linick TW. 1978. La Jolla measurements of radiocarbon in the oceans. Radiocarbon 20(3):333-59.

Manning MR, Melhuish WH. 1994. Atmospheric $\Delta^{14} \mathrm{C}$ record from Wellington. In: Boden TA, editor. Trends '93: a compendium of data on global change. Oak Ridge, Tennessee: Oak Ridge National Laboratory. Carbon Dioxide Information Analysis Center Publication. ORNL/CDIAC-65. p 193-202.

Monterey GI, Levitus S. 1997. Seasonal variability of mixed layer depth for the world ocean. Washington DC: US Goverment Printing Office. NOAA NESDIS Atlas 14.

Moore MD, Schrag DP, Kashgarian M. 1997. Coral radiocarbon constraints on the source of the Indonesian throughflow. Journal of Geophysical Research 102: 12,359-65.

Pickard GL, Emery WJ. 1982. Descriptive physical oceanography. New York: Permagon Press. 249 p.

Östlund G, Stuiver M. 1980. GEOSECS Pacific radiocarbon. Radiocarbon 22(1):25-53.

Quay PD, Stuiver M, Broecker WS. 1983. Upwelling rates for the equatorial Pacific Ocean derived from the bomb ${ }^{14} \mathrm{C}$ distribution. Journal of Marine Research 41:769-92.

Rajagopalan B, Lall U, Cane MA. 1997. Anomalous ENSO occurrences: an alternate view. Journal of Climate 10:2351-7.

Reynolds RW, Smith TM. 1994. Improved global sea surface temperature analyses. Journal of Climate 7:92948.

Rodgers KB, Schrag DP, Cane MA, Naik NH. 1999. The bomb- ${ }^{14} \mathrm{C}$ transient in the Pacific ocean. Journal of Geophysical Research. Forthcoming.

Rodgers KB, Cane MA, Schrag DP. 1997. Seasonal variability of sea surface $\Delta^{14} \mathrm{C}$ in the equatorial Pacific in an ocean circulation model. Journal of Geophysical Research 102:18627-39.

Schrag DP. 1999. Rapid analysis of high-precision Sr/Ca ratios in corals and other marine carbonates. Paleoceanography 14:97-102.

Stuiver M, Polach HA. 1977. Discussion and reporting of ${ }^{14} \mathrm{C}$ data. Radiocarbon 19(3):355-363.

Stuiver M, Pearson, GW Braziunas T. 1986. Radiocarbon age calibration of marine samples back to $9000 \mathrm{cal} \mathrm{yr}$ BP. Radiocarbon 28(2B):980-1021.

Toggweiler JR, Dixon K, Broecker WS. 1991. The Peru upwelling and the ventilation of the South Pacific thermocline. Journal of Geophysical Research 96: 20467-97.

Trenberth KE, Hoar TJ. 1996. The 1990-1995 El NiñoSouthern Oscillation event: longest on record. Geophysical Research Letters 23:57-60.

Tsuchiya M, Lukas R, Fine RA, Firing E, Lindstrom E. 1968. Upper waters of the intertropical Pacific Ocean. Johns Hopkins Oceanographic Studies 4. 50 p.

Tsuchiya M et al. 1989. Source waters of the Pacific equatorial undercurrent. Progress in Oceanography 23:101-47.

Vogel JS, Southon JR, Nelson DE. 1987. Catalyst and binder effects in the use of filamentous graphite for AMS. Nuclear Instruments and Methods in Physics Research B29:50-6.

Wyrtki K, Kilonsky B. 1984. Mean water and current structure during the Hawaii to Tahiti shuttle experiments. Journal of Physical Oceanography 14:242-54.

Zebiak SE, Cane MA. 1991. Natural climate variability in a coupled model. New York: Elsevier. p 457-70. 